Kajian Analisis Suhu dan Lama Penyimpanan - Setiawati, dkk

Jurnal Pangan dan Agroindustri Vol.6 No.4: 77-86, Oktober 2018

\title{
KAJIAN ANALISIS SUHU DAN LAMA PENYIMPANAN TERHADAP KARAKTERISTIK KADAR ALKOHOL KEFIR SUSU SAPI
}

\section{Study of Temperature Analysis and Storage towards Alcohol Level in Cow Milk Kefir}

\author{
Azizah Eddy Setiawati ${ }^{1 *}$, Yunianta ${ }^{1}$ \\ Jurusan Teknologi Hasil Pertanian, FTP Universitas Brawijaya Malang \\ Jl. Veteran, Malang 65145 \\ *Penulis Korespondensi, azizah_es@yahoo.co.id
}

\begin{abstract}
ABSTRAK
Kefir adalah susu fermentasi dengan aroma yeasty. Kefir diproses melalui susu pasteurisasi menggunakan starter biji kefir. Tujuan penelitian ini untuk mengetahui pengaruh suhu dan lama penyimpanan terhadap kadar alkohol kefir susu sapi. Metode penelitian yang digunakan adalah Rancangan Acak Kelompok Faktorial dengan dua faktor dan tiga level. Faktor yang digunakan adalah lama penyimpanan selama 7, 14 , dan 21 hari serta suhu penyimpanan pembekuan $\left(-10^{\circ} \mathrm{C}\right)$, pendinginan $\left(15^{\circ} \mathrm{C}\right)$, dan suhu ruang $\left(20^{\circ} \mathrm{C}\right)$. Analisis menggunakan ANNOVA, uji lanjut DMRT 95\%, Zeleny. Hasil menunjukkan bahwa adanya interaksi antara lama penyimpanan dengan suhu penyimpanan yang nyata $(\alpha=$ 0.05). Hasil perlakuan terbaik adalah penyimpanan suhu $\left(-10^{\circ} \mathrm{C}\right)$ hari ke 7 dengan karakteristik pH sebesar 4.47 , TPT sebesar $10.00 \%$ Brix, total gula sebesar $3.07 \%$, total asam sebesar $0.26 \%$, kadar alkohol sebesar $0.04 \%$, total bakteri asam laktat sebesar 5.91 Log CFU/ml dan total khamir sebesar 6.56 Log CFU/ml
\end{abstract}

Kata kunci: Alkohol, Kefir, Lama Penyimpanan, Suhu Penyimpanan

\section{ABSTRACT}

Kefir is a fermented milk product with yeasty aroma. Kefir is processed by fermentation of pasteurized milk using kefir grain. The aim of this study was to determine the effect of temperature and storage time on alcohol content of cow's milk kefir. The research method used Randomized Block Design Factorial with two factors and three levels. The first factor were storage time that consist of 7, 14, and 21 days. While the second factor was storage temperature that consists of freezing storage $\left(-10^{\circ} \mathrm{C}\right)$, refrigerator storage ($\left.15^{\circ} \mathrm{C}\right)$, and room storage $\left(-20^{\circ} \mathrm{C}\right)$. Data were analysed using ANNOVA, DMRT $95 \%$ and Zeleny. The results showed that the interaction between storage time and variant of storage temperature was significant $(\alpha=0.05)$. The best treatment result was attributed to freezer storage day 7 and characteristic are $\mathrm{pH}$ of 4.47 , total soluble solids of $10.00 \%$ Brix, sugar total (3.07\%), total acid (0.26\%), alcohol content $(0.04 \%)$, the total of lactic acid bacteria (5.91 Log CFU/ml) and the total of yeast (6.56 Log CFU/ml).

Keywords: Alcohol, Kefir, Storage Time, Storage Temperature

\section{PENDAHULUAN}

Dewasa ini, konsumsi susu oleh masyarakat Indonesia terbilang rendah dengan kisaran 11.09 liter per kapita per tahun. Pasokan bahan baku susu segar sebesar 690 ribu ton atau sekitar $21 \%$ dari jumlah total bahan yang dibutuhkan. Sisa bahan baku yang dibutuhkan untuk membuat olahan susu dipasok melalui impor dalam bentuk skim milk powder, anhydrous milk fat, dan butter milk powder dari berbagai negara seperti Australia, New Zealand, Amerika 
Serikat, dan Uni Eropa (Kemenperin, 2014). Susu dapat diolah menjadi berbagai produk salah satunya produk fermentasi. Beberapa jenis produk susu yang difermentasi adalah yoghurt, susu asidofilus, koumiss, kefir, dan lain lain (Wijayaningsih, 2008). Salah satu produk olahan susu fermentasi yang saat ini banyak dikembangkan adalah kefir.

Kefir adalah susu fermentasi dengan warna, rasa dan konsistensi seperti yoghurt dan memiliki aroma khas yeasty (seperti tape). Kandungan dari kefir antara lain, asam laktat kefir sekitar $0.8-1.1 \%$, alkohol $0.5-2.5 \%$, adanya sedikit gas karbon dioksida, kelompok vitamin B serta diasetil dan asetaldehid. Kadar nutrisi kefir yaitu air $89.5 \%$, lemak $1.5 \%$, protein $3.5 \%$, abu $0.6 \%$, laktosa $4.5 \%$ dengan nilai pH 4.6 (BB-Pasca Panen, 2007). Kandungan alkohol yang cukup tinggi tersebut, dihasilkan oleh khamir. Khamir merupakan mikroorganisme yang membantu dalam proses pembentukan alkohol. Peningkatan kadar alkohol juga disebabkan oleh khamir yang memecah gula sederhana menjadi alkohol dan karbondioksida (Yusriah dan Agustini, 2014). Jenis alkohol yang dihasilkan oleh khamir adalah etanol (Usmiati, 2007).

Berdasarkan uraian diatas, menjadi latar belakang peneliti untuk melakukan penelitian ini. Tujuan dilakukannya penelitian ini adalah untuk mengetahui pengaruh dari penyimpanan dan lama penyimpanan terhadap kadar alkohol kefir. Mengetahui kombinasi perlakuan yang efektif untuk menghasilkan kadar alkohol yang terendah.

\section{Bahan}

\section{BAHAN DAN METODE}

Bahan utama yang diperlukan dalam penelitian ini adalah susu segar dan bibit kefir yang didapatkan dari Balai Besar Pelatihan Peternakan Kota Batu. Adapun bahan yang digunakan untuk analisis adalah larutan buffer $\mathrm{pH} 4$ dan 7, kertas saring, indikator phenolphtalin, $\mathrm{NaOH} 0.1 \mathrm{~N}, \mathrm{CaCO}$, reagen anthrone, media MRSA merk MERCK, PDA merk MERCK, pepton merk MERCK, aquadest merk Hydrobate dan alkohol 96\%. Beberapa bahan tambahan yang diperlukan yaitu kertas payung, plastik PE, karet, stiker label, dan tisu..

\section{Alat}

Alat yang digunakan adalah wadah plastik, toples plastik, saringan plastik, dan sendok plastik yang dibeli di pasar Oro-oro Dowo. Adapun gelas beaker $50 \mathrm{ml}, 200 \mathrm{ml}$, cawan petri, labu ukur $100 \mathrm{ml}$, erlenmeyer $1000 \mathrm{ml}, 500 \mathrm{ml}$ dan $250 \mathrm{ml}$. Tambahan lainnya yaitu statif, buret, tabung reaksi, jar ukuran $200 \mathrm{ml}$, pipet tetes, pipet ukur $10 \mathrm{ml}$ dan $1 \mathrm{ml}, \mathrm{kuvet}$, timbangananalitik,penangas, GC FID, Hannah pH meter, hand Refractometer spektrofotometer, inkubator dan colony counter.

\section{Rancangan Pencobaan}

Metode yang digunakan dalam penelitian ini adalah Rancangan Acak Kelompok (RAK) yang disusun secara faktorial dengan 2 faktor. Faktor pertama (I) terdiri dari 3 level dan faktor kedua II terdiri dari 3 level sehingga didapatkan 9 kombinasi perlakuan. Masing-masing perlakuan diulang sebanyak 3 kali sehingga didapatkan 27 satuan percobaan. Data hasil pengamatan yang telah dilakukan dianalisis menggunakan statistik. Adapun metode yang digunakan adalah Analysis of Variance (ANOVA) dengan selang kepercayaan 5\%, dan sidik ragam. Apabila dari hasil uji yang telah dilakukan menunjukkan adanya terjadi pengaruh, maka dapat dilakukan untuk uji lanjut yaitu BNT (Beda Nyata Terkecil) atau DMRT (Duncan Multiple Range Test) dengan menggunakan selang kepercayaan 5\%.

\section{Pembuatan Sampel}

Susu segar sebanyak $200 \mathrm{ml}$ dipasteurisasi pada suhu $70^{\circ} \mathrm{C}$ selama 10 menit. Lalu didinginkan cepat sampai pada suhu suhu $30^{\circ} \mathrm{C}$ dimasukkan dalam toples plastik. Sampai pada tahapan ini,kemudian dilakukan uji bahan baku. Ditambahkan bibit kefir sebanyak $4 \%(b / v)$ lalu dilakukan fermentasi selama 24 jam. Setelah proses tersebut, kefir disaring untuk memisahkan bibit dan hasil kefir. Kemudian, dilakukan untuk uji sampel. 
Kajian Analisis Suhu dan Lama Penyimpanan - Setiawati, dkk

Jurnal Pangan dan Agroindustri Vol.6 No.4: 77-86, Oktober 2018

\section{Pegamatan Penelitian}

- pH (Derajat Keasaman)

Sampel dtimbang 10 gram kemudian dilarutkan dalam $50 \mathrm{ml}$ aquades dalam gelas bekker. Diukur dengan mencelupkan pH meter dalam sampel. Dicatat angka yang muncul pada indikator angka $\mathrm{pH}$ meter.

- Totas Asam

Sampel diambil sebanyak $10 \mathrm{ml}$ kemudian masukkan dalam labu ukur $100 \mathrm{ml}$ dtambahkan akuades sampai tanda batas dan dihomogenkan kemudian disaring. Filtrat diambil sebnayak $10 \mathrm{ml}$ dimasukkan dalam erlenmeyer, tambhakan indikator PP sebanyak 2-3 tetes. Kemudian, di titrasi menggunakan $\mathrm{NaOH} \mathrm{0,1} \mathrm{N} \mathrm{sampai}$ warnanya berubah menjadi merah muda. Hasil titrasi dimasukkan kedalam rumus, Rumusnya : Total asam (\%) $=\underline{(\mathrm{V} \times \mathrm{N} \times \mathrm{FP} \times \mathrm{BE} \text { asam } \times 100 \%)}$

- Total Gula

(Berat sampel $\times 1000$ )

Sampel ditimbang sebanyak $5 \mathrm{ml}$ diberi akuades sebanyak $95 \mathrm{ml}$ kemudian ditambahkan 1 gram $\mathrm{CaCO}_{3}$ dan aduk sampai rata. Dipanaskan pada penangas dengan suhu $100^{\circ} \mathrm{C}$ selama kurang lebih 30 menit. Sampel disaring menggunakan kertas saring. Kemudian ambil sampel $1 \mathrm{ml}$, masukkan kedalam labu ukur $100 \mathrm{ml}$. Tambahkan akuades sampai tanda batas dan didapatkan filtrat dari sampel. Filtrat yang sudah didapatkan diambil sebanyak $1 \mathrm{ml}$ masukkan kedalam tabung reaksi. Ditambahkan $5 \mathrm{ml}$ perekasi anthrone dengan cepat kedalam tabung rekais yang berisi filtrat. Tabung reaksi di tutup dan dicampur hingga rata. Dipanaskan dengan suhu $100^{\circ} \mathrm{C}$ selama kurang lebih 15 menit. Dinginkan dengan air mengalir kemudian dilakukan pengecekan absorbansi menggunakan spektrofotometer. Sampel dimasukkan kedalam kuvet dannilai absorbansinya akan terbaca, absorbansi yang digunakan adalah $630 \mathrm{~nm}$.

Rumusnya : \%Total gula $=\underline{\text { FP } x \text { konsentrasi }(x) \times 100 \% \times \text { volume filtrat }}$

berat sampel $(\mathrm{mg})$

- Kadar Alkohol

Sampel dilakukan preparasi dengan awal diambil sebanyak sebanyak 400 mikrolit kemudian ditambahakna 200 mikrolit asetonitril. Diukur asetonitril dan kadar etanol menggunakan Gas Chromatography. Dicatat hasilnya kemudian diambil sampel sebanyak 0.4 mikrolit. Klik start pada alat kemudian injeksikan pada Gas Chromatography dan ditunggu sampai menit ke-13. Ditekan menu analyzed, klik display-peak report kedian di save.

- Total Padatan Terlarut

Sebanyak 1 tetes sampel diteteskan pada prisma refraktometer yang telah dikalibrasi dengan akuades. Arahkan refraktometer ke sumber cahaya. Nilai yang terbaca menunjukkan besarnya total padatan terlarut pada sampel dalam satuan $\%$ Brix.

Sampel diambil sebanyak

- Total BAL

Sampel diambil sebanyak $1 \mathrm{ml}$ kemudian dimasukkan dalam tabung reaksi yang berisi $9 \mathrm{ml}$ larutan pepton steril. Kemudian lakukan pengenceran. Diambil $1 \mathrm{ml}$ dari tabung reaksi pada 3 pegenceran terakhir untuk dimasukkan kedalam cawan petri steril. Lalu, tuang media MRSA steril (hangat) sampai dasar cawan tertutup media. Setelah memadat, diinkubasi pada suhu $37^{\circ} \mathrm{C}$ selama 48 jam. Setelah itu di catat jumlah pertumbuhan koloni pada setiap cawannya.

- Total Khamir

Sampel diambil sebanyak $1 \mathrm{ml}$ kemudian dimasukkan dalam tabung reaksi yang berisi $9 \mathrm{ml}$ larutan pepton steril. Kemudian lakukan pengenceran. Diambil $1 \mathrm{ml}$ dari tabung rekasi pada 3 pegenceran terakhir untuk dimasukkan kedalam cawan petri steril. Lalu, tuang media PDA steril (hangat) sampai dasar cawan tertutup 
media. Setelah memadat, diinkubasi pada suhu $30^{\circ} \mathrm{C}$ selama 48 jam. Setelah itu di catat jumlah pertumbuhan koloni pada setiap cawannya.

\section{HASIL DAN PEMBAHASAN}

\section{Hasil Analisis Bahan Baku}

\begin{tabular}{lll}
\hline Parameter & Hasil Analisis & Literatur \\
\hline Total Asam (\%) & $0.17 \pm 0.009$ & $0.15^{\mathrm{a}}$ \\
Derajat Keasaman $(\mathrm{pH})$ & $6.27 \pm 0.057$ & $5.0-6.9^{\mathrm{b}}$ \\
Total Gula (\%) & $4.39 \pm 0.081$ & $4.4 \pm 0.022^{\mathrm{c}}$ \\
Total Padatan Terlarut (\%Brix) & $9.33 \pm 0.057$ & $5.1-13.4^{\mathrm{d}}$ \\
Total Bakteri Asam Laktat (log cfu/ml) & $5.51 \pm 0.026$ & $5 \times 10^{5} \mathrm{e}$ \\
Total Khamir (log cfu/ml) & $6.58 \pm 0.044$ & $5 \times 10^{5 \mathrm{f}}$ \\
Kadar Alkohol (\%) & $<\mathrm{LOQ}$ & Negatif $\mathrm{g}$ \\
\hline
\end{tabular}

Keterangan:

1. Setiap data adalah rerata 3 kali ulangan

2. Angka di belakang simbol adalah standard deviasi

3. Abjad setelah angka merupakan sitasi dari literatur yang menyatakan persamaan dengan data analisis
a. Hosain (2012)
b. Surono (2004)
c. Hosain (2012)
d. Mooree (2009)
e. TAS $6003(2010)$
f. TAS $6003(2010)$
g. TAS $6003(2010)$

Pada tabel diatas menunjukkan adanya perbedaan antara analisis bahan baku jika dibandingkan dengan literatur. Pada parameter total asam terlihat hasil analisis menunjukkan nilai $0.17 \pm 0.009 \%$ jika dibandingkan dengan literatur yaitu $0.15 \%$ hal tersebut dapat terjadi dipengaruhi oleh jenis susu yang digunakan, peningkatan yang terjadi juga dapat dikarenakan adanya mikroba yang aktif memanfaatkan karbohidrat yang dapat difermentasi dan menghasilkan asam-asam organik, total asam yang terhitung menyatakan kandungan jumlah asam laktat (Purwanti, 2013).

Pada parameter derajat keasaman $(\mathrm{pH})$ yang dihasilkan dari hasil analisis yaitu 6.27 \pm 0.057 , jika di bandingkan dengan literatur yaitu sekitar 5.0 - 6.9 maka dapat dikatakan sudah sesuai dengan literatur. Adapun parameter lainnya yaitu total gula menunjukkan nilai $4.39 \pm$ $0.081 \%$ jika dibandingkan dengan literatur yaitu $4.4 \pm 0.022 \%$ dapat dikatakan sudah sesuai. Parameter lainnya yaitu total padatan terlarut, dari hasil analisis yang telah dilakukan menunjukkan $9.33 \pm 0.057$ \%Brix, jika di bandingkan literatur yaitu dengan kisaran rentang 5.1 - 13.4 maka dapat dikatakan hasil analisis sudah sesuai dengan literatur.

Parameter lainya yaitu total bakteri asam laktat dan total khamir. Hasil analisis yang telah dilakukan total bakteri asam laktat pada bahan baku yaitu $5.51 \pm 0.026 \mathrm{log} \mathrm{cfu} / \mathrm{ml}$, dan total khamir yaitu $6.58 \pm 0.044 \mathrm{log} \mathrm{cfu} / \mathrm{ml}$. Apabila dibandingkan dengan literatur cemaran yang diperbolehkan yaitu $5 \times 10^{5}$ ada perbedaan antara hasil analisis dengan literatur. Hal tersebut dapat terjadi dikarenakan kemungkinan terjadinya kontaminasi pada sampel susu pasteurisasi saat dilakukan proses pengujian (Surono, 2004).

Parameter terakhir yaitu kadar alkohol pada bahan baku. Pada pengujian kadar alkohol menggunakan GC-FID tidak terdeteksi adanya kandungan alkohol pada bahan baku atau dapat dikatakan hasilnya negatif. Hal tersebut ditandai dengan hasil yang menunjukkan $<\mathrm{LOQ}$. LOQ adalah Limit of Quantification. Hasil tersebut sudah sesuai dengan literatur. 


\section{Hasil Analisis Sampel}

1. Derajat Keasaman

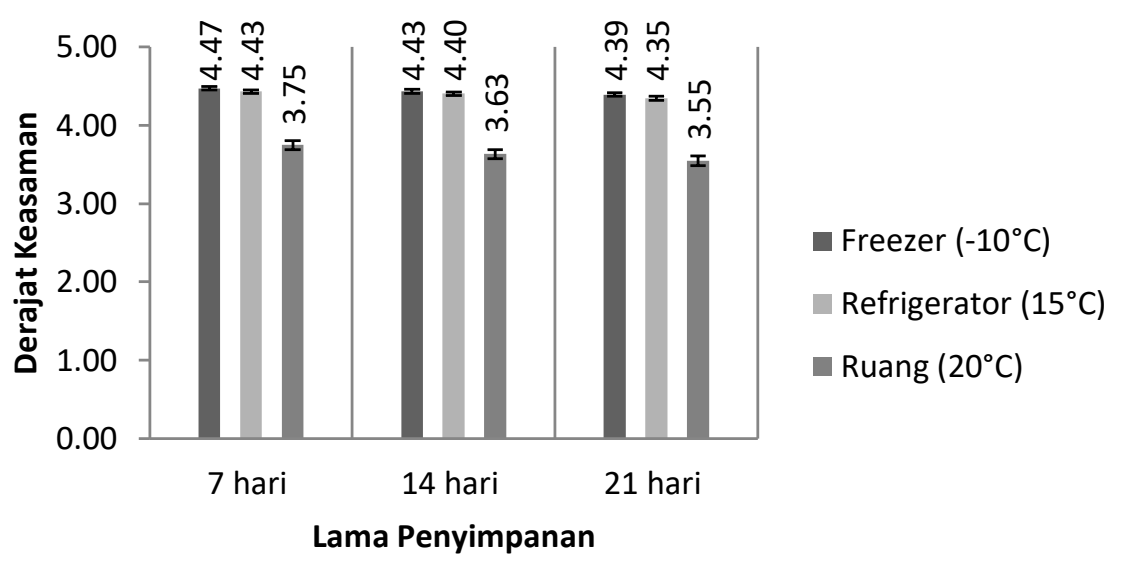

Gambar 1. Derajat Keasaman

Adanya perubahan nilai $\mathrm{pH}$ yang dapat mengubah cita rasa dari suatu produk pangan. Produk pangan dengan keasaman rendah umumnya cenderung lebih awet karena mikroba akan sulit tumbuh pada media dengan tingkat keasaman tinggi (Sukandar, 2014). Hasil analisis menunjukkan semakin lama penyimpanan maka nilai $\mathrm{pH}$ yang dihasilkan semakin menurun. Menurut Mal (2015) Lama penyimpanan memilki pengaruh pada $\mathrm{pH}$. Penurunan $\mathrm{pH}$ yang terjadi diakibatkan oleh aktivitas bakteri asam laktat dan khamir yang berasal dari kefir grain. Sedangkan pada hasil analisis menunjukkan dengan adanya berbagai varian suhu menyebabkan $\mathrm{pH}$ menjadi semakin menurun karena penyimpanan pada suhu rendah menyebabkan terhambatnya pertumbuhan bakteri sehingga menghambat terjadinya perubahan biokimia, fisik dari produk pangan sehingga dapat memperpanjang umur simpan (Usmiati, 2007).

\section{Total Asam}

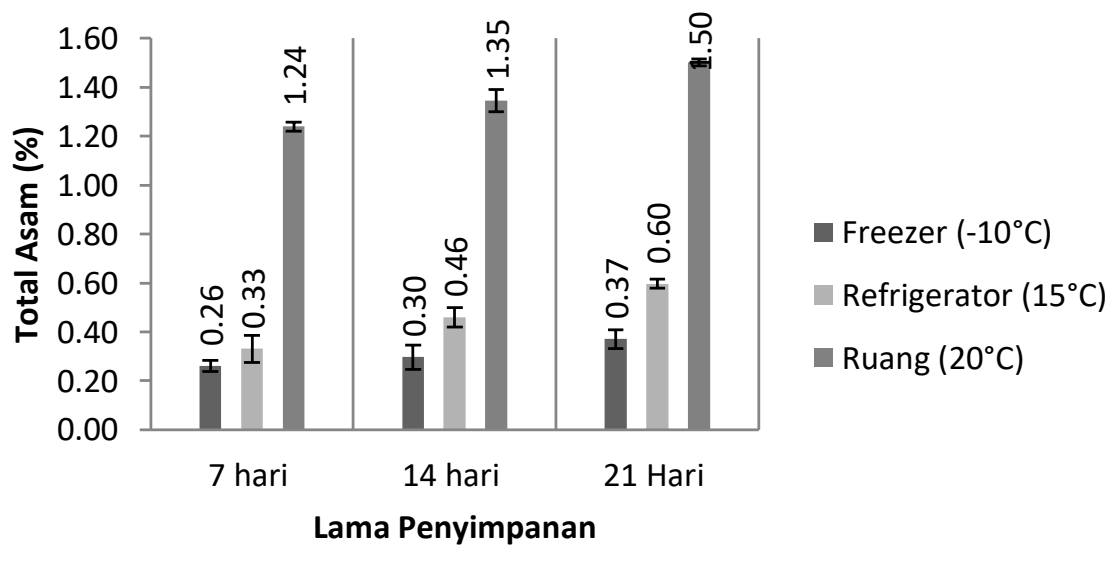

Gambar 2. Total asam

Total asam tertitrasi merupakan manifestasi dari kadar asam laktat dari produk yang terdisosiasi maupun yang tidak terdisosiasi (Zakaria, 2013). Hasil analisis menunjukkan semakin lama penyimpanan maka nilai total asam yang dihasilkan semakin meningkat. Menurut Mal (2015) Lama penyimpanan memilki pengaruh pada total asam. Peningkatan total asam yang terjadi diakibatkan penurunan $\mathrm{pH}$, dengan adanya $\mathrm{pH}$ yang rendah menjadikan lingkungan untuk bakteri asam laktat tumbuh, sehingga menghasilkan metabolit 
asam laktat. Sedangkan pada hasil analisis menunjukkan dengan adanya berbagai varian suhu menyebabkan total asam menjadi semakin meningkat karena pertumbuhan mikroorganise dipengaruhi oleh suplai zat gizi, suhu, waktu, air dan kesediaan oksigen. Dengan semakin banyaknya hasil metabolit asam laktat yang dihasilkan menandakan bahwa terjadi pertumbuhan bakteri asam laktat (Rosiana, 2013).

3. Total Gula

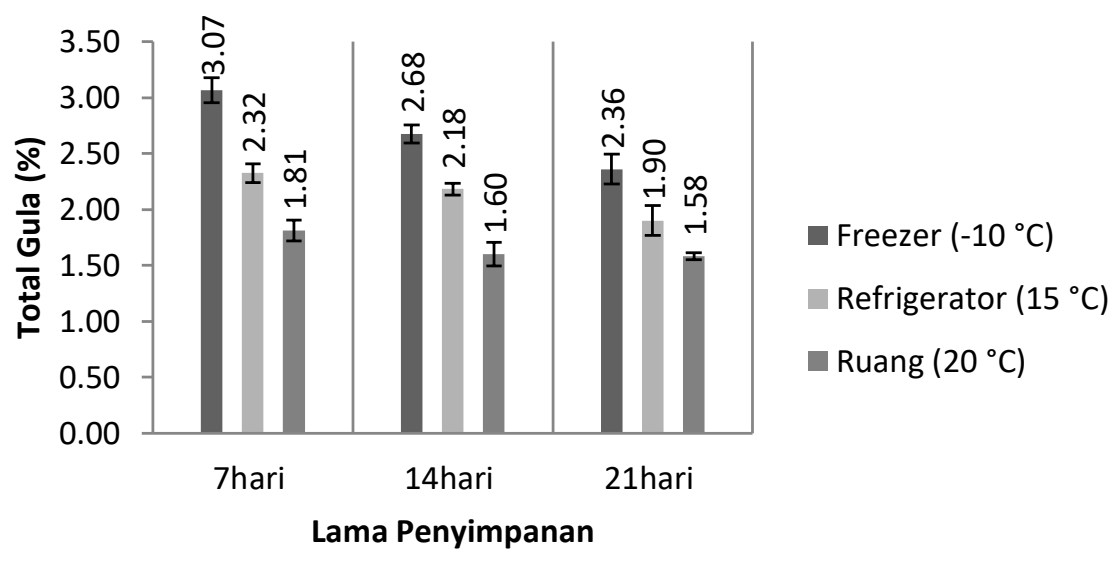

Gambar 3. Total gula

Kadar gula total adalah kandungan gula keseluruhan pada suatu bahan pangan baik itu gula pereduksi maupun gula non pereduksi dan semua jenis karbohidrat dari golongan monosakarida, disakarida, oligosakarida dan polisakarida (Kinanti, 2014). Hasil analisis menunjukkan semakin lama penyimpanan maka nilai total gula yang dihasilkan semakin menurun. Menurut Jeanette (2015) gula merupakan komponen gizi dalam produk yang juga dimanfaatkan oleh bakteri asam laktat dalam menghasilkan metabolit. Semakin lama penyimpanan maka semakin banyak nutrisi yang dimakan untuk melakukan proses metabolisme. Pada hasil analisis menunjukkan dengan adanya berbagai varian suhu menyebabkan total gula menjadi semakin menurun karena suhu pertumbuhan bakteri asam laktat adalah $10^{\circ} \mathrm{C}-40^{\circ} \mathrm{C}$ dengan suhu optimum $30-37^{\circ} \mathrm{C}$. Saat mikroorganisme tidak pada suhu optimum maka perkembangan metabolisme yang terjadi tidak optimum (Mallesha, 2010).

\section{Total Padatan Terlarut}

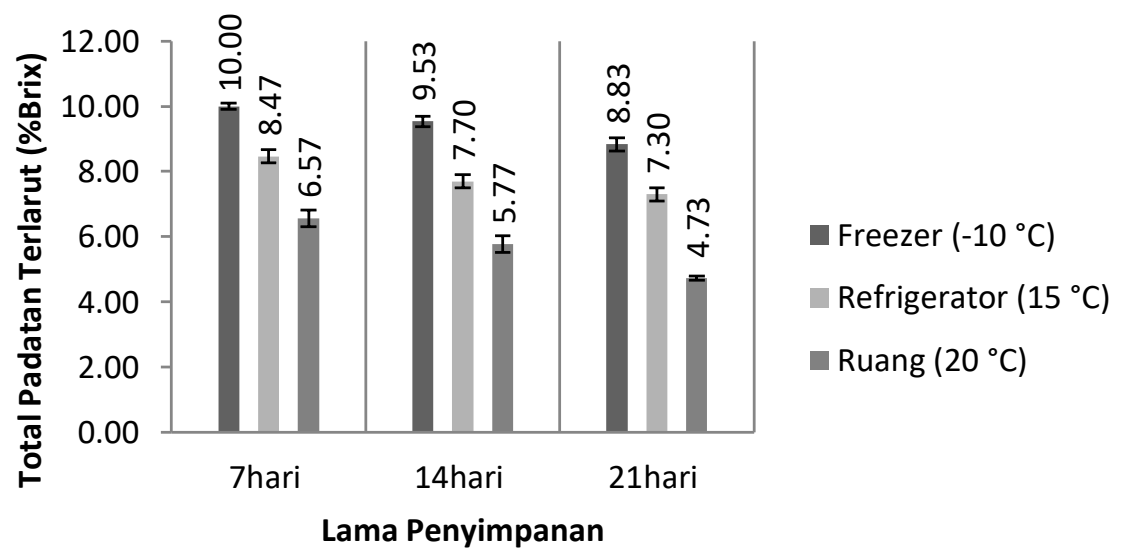

Gambar 4. Total Padatan Terlarut 
Total padatan terlarut adalah bahan-bahan terlarut dengan diameter $<10^{-6} \mathrm{~mm}$ dan koloid yang berupa senyawa kimia ataupun bahan-bahan lain yang tidak tersaring oleh kertas saring dengan diameter $0.45 \mu \mathrm{m}$, merupakan suatu jumlah material terlarut air dalam suatu bahan meliputi total gula, asam organik, pektin dan protein (Desrosier, 2008). Hasil analisis menunjukkan semakin lama penyimpanan maka nilai total padatan terlarut yang dihasilkan semakin menurun. Pada hasil analisis menunjukkan dengan adanya berbagai varian suhu menyebabkan total padatan terlarut menjadi semakin menurun karena adanya kombinasi pengaruh suhu dan lama penyimpanan. Hilangnya komponen zat gizi pada pembekuan, adanya pemutusan karbohidrat menjadi lebih sederhana sebagai sumber nutrisi mikroorganisme yang menyebabkan menurunnya total padatan terlarut (Prastyanto, 2016).

5. Total Bakteri Asam Laktat

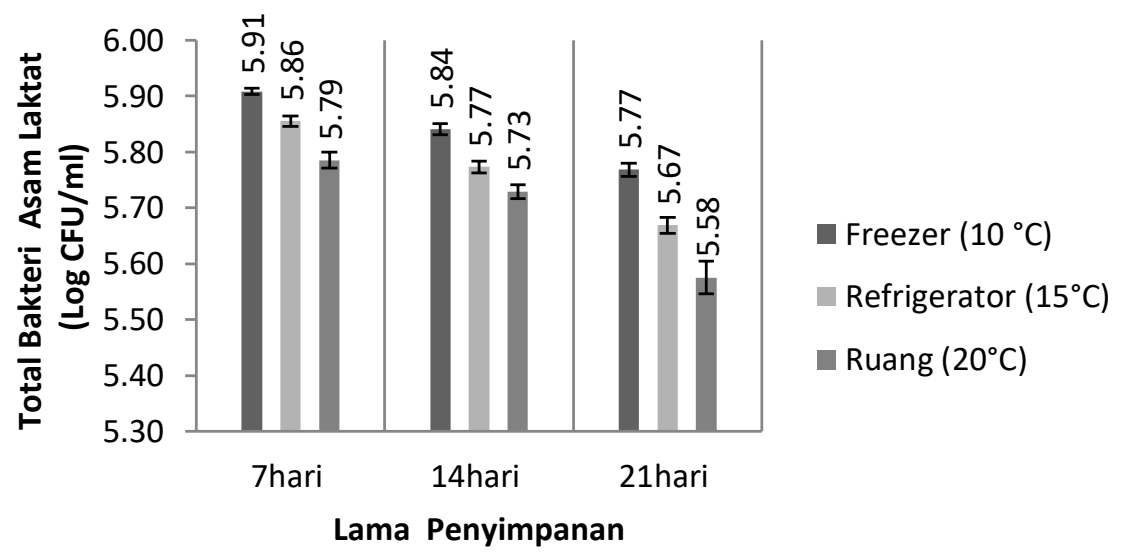

Gambar 5. Total Bakteri Asam Laktat

Bakteri asam laktat merupakan bateri gram positif dengan bentuk kokus ataupun bayang tidak berspora. Hasil metabolisme utamanya yaitu asam laktat. Bakteri asam laktat juga sering digunakan sebagai starter kultur untuk susu fermentasi. Bakteri ini dikatakan sebagai bakteri asidurik karena $\mathrm{pH}$ yang relatif rendah dalam perkembangannya yaitu sekitar 5,4-4,6 (Malaka, 2005). Hasil analisis menunjukkan semakin lama penyimpanan maka nilai total bakteri asam laktat yang dihasilkan semakin menurun. Menurut Indah (2017) lama penyimpananakan menurunkan total bakteri asam laktat, dikarenakan hasil dari asam laktat yang meningkat menyebabkan $\mathrm{pH}$ menurun, namun bakteri asam laktat itu sendiri juga tidak tahan dengan kondisi yang terlalu asam, sehingga bakteri akan mati/lisis. Sedangkan pada hasil analisis menunjukkan dengan adanya berbagai varian suhu menyebabkan total bakteri asam laktat menjadi semakin menurun karena suhu pertumbuhan bakteri asam laktat adalah $10^{\circ} \mathrm{C}-40^{\circ} \mathrm{C}$ dengan suhu optimum $30-37^{\circ} \mathrm{C}$. Saat mikroorganisme tidak pada suhu optimum maka perkembangan metabolisme yang terjadi tidak optimum (Mallesha, 2010). Proses fermentasi BAL akan memanfaatkan karbohidrat yang ada hingga terbentuk asam laktat, hingga terjadi penurunan nilai $\mathrm{pH}$ dan peningkatan keasaman (Hidayat, 2013).

\section{Total Khamir}

Khamir merupakan organisme uniseluler dengan sistem reproduksi aseksual spora.Pada produk susu, khamir berperan dalam menyediakan nutrisi untuk mikroba lain seperti asam amino, vitamin, mengkondisikan keadaan $\mathrm{pH}$. Nutrisi tersebut tersedia karena ada proses fermentasi aerob sebelumnya, yaitu khamir memecah glukosa menjadi alkohol dan karbondioksida (Wijaningsih, 2008). Hasil analisis menunjukkan semakin lama penyimpanan maka nilai total khamir yang dihasilkan semakin meningkat. Menurut Yulneriwarni (2008) lama penyimpanan dapat meningkatkan total khamir karena adanya 
kemampuan khamir dalam memecah substrat gula menjadi lebih sederhana untuk nutrisinya dengan bantuan dari bakteri asam laktat sebelumnya. Sedangkan pada hasil analisis menunjukkan dengan adanya berbagai varian suhu menyebabkan total khamir menjadi semakin meningkat karena pertumbuhan bakteri khamir adalah $5^{\circ} \mathrm{C}-50^{\circ} \mathrm{C}$, memiliki suhu optimum $25-30^{\circ} \mathrm{C}$. Saat khamir tidak pada suhu optimum proses perkembangan dari khamir menjadi tidak optimal (Mal et al, 2015).

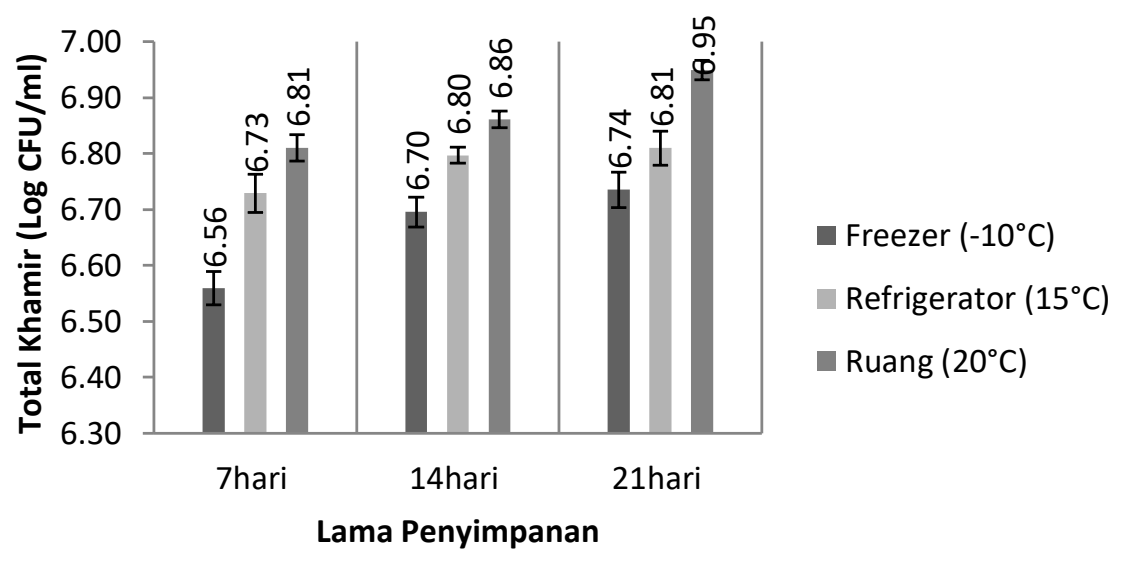

Gambar 6. Total Khamir

7. Kadar Alkohol

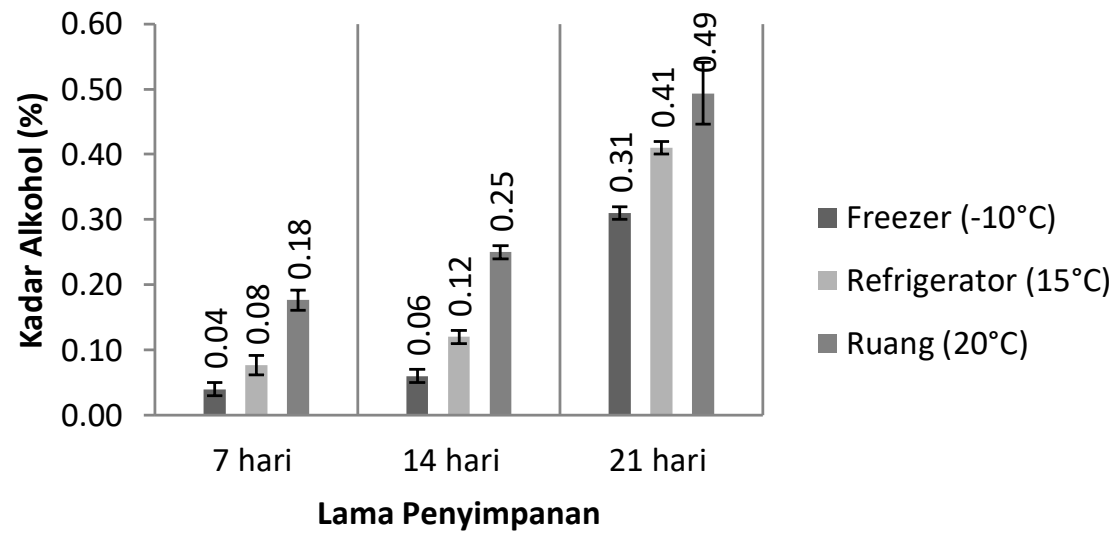

Gambar 7. Kadar alkohol

Alkohol adalah istilah umum untuk senyawa organik apapun yang memiliki gugus fungsional atau yang disebut gugus hidroksil $(-\mathrm{OH})$ yang terikat pada atom karbon. Memiliki rumus umum $\mathrm{R}-\mathrm{OH}$ atau $\mathrm{Ar}-\mathrm{OH}$ ( $\mathrm{R}$ adalah gugus alkill dan Ar adalah gugus aril). Minuman yang mengandung alkohol adalah minuman yang mengandung etanol dan senyawa lain seperti metanol, asetaldehida,dll. Dibuat melalui proses fermentasi dengan rekayasa dengan berbagai jenis bahan (MUI, 2009). Menurut Wijaningsih (2008) lama penyimpanan memiliki pengaruh terhadap kadar alkohol kefir. Semakin lama penyimpanan maka akan semakin meningkatkan kadar alkohol pada produk kefir dapat diakibatkan oleh pertumbuhan khamir. Pada hasil analisis menunjukkan dengan adanya berbagai varian suhu menyebabkan kadar alkohol menjadi semakin meningkat karena semakin tinggi suhu maka semakin meningkatkan kadar alkohol. Alkohol dapat meningkat, karena suhu optimumnya adalah suhu ruang,dan pada suhu rendah pertumbuhan mikroba pembentuk alkohol akan terhambat (Usmiati, 2007). 


\section{Perlakuan Terbaik}

Pemilihan perlakuan terbaik pada produk kefir susu sapi dengan lama penyimpanan dan berbagai variasi suhu penyimpanan dengan menggunakan Multiple Attribute (Zeleny, 1982), dimana setiap parameter dianggap memiliki bobot yang sama penting. Atribut adalah sifat-sifat obyek yang aktual, atau sifat-sifat obyek yang diberikan secara subyektif. Multiple Attribute dalam penggunaannya berdasarkan kebutuhan dan harapan pembuat Keputusan. Metode Multiple Attribute ditujukan untuk membantu dan mengembangkan kepercayaan bagi pengambil keputusan untuk memikirkan penyelesaian terbaik (Agustawa, 2012). Berdasarkan hasil perhitungan nilai perlakuan terbaik didapatkan pada kefir susu sapi perlakuan terbaik terhadap sifat fisik, kimia dan mikrobiologi yaitu pada lama penyimpanan 7 hari pada kondisi freezer (S1L1).

Tabel 1. Profil kefir susu sapi

\begin{tabular}{|c|c|c|c|c|c|c|c|}
\hline Perlakuan & $\begin{array}{l}\text { Total } \\
\text { Asam }\end{array}$ & $\mathrm{pH}$ & $\begin{array}{l}\text { Total } \\
\text { Gula }\end{array}$ & TPT & BAL & Khamir & Alkohol \\
\hline $\begin{array}{l}\text { Freezer } 7 \\
\text { Hari }\end{array}$ & $0.26 \pm 0.02$ & $4.47 \pm 0.03$ & $3.07 \pm 0.11$ & $10.00 \pm 0.06$ & $5.91 \pm 0.01$ & $6.56 \pm 0.05$ & $0.04 \pm 0.01$ \\
\hline $\begin{array}{l}\text { Refrigerator } \\
7 \text { Hari }\end{array}$ & $0.33 \pm 0.06$ & $4.43 \pm 0.08$ & $2.32 \pm 0.08$ & $8.47 \pm 0.10$ & $5.86 \pm 0.01$ & $6.73 \pm 0.02$ & $0.08 \pm 0.02$ \\
\hline $\begin{array}{l}\text { Ruang } 7 \\
\text { Hari }\end{array}$ & $1.24 \pm 0.02$ & $3.75 \pm 0.02$ & $1.81 \pm 0.09$ & $6.57 \pm 0.10$ & $5.79 \pm 0.01$ & $6.81 \pm 0.03$ & $0.18 \pm 0.02$ \\
\hline $\begin{array}{l}\text { Freezer } 14 \\
\text { Hari }\end{array}$ & $0.30 \pm 0.06$ & $4.43 \pm 0.02$ & $2.68 \pm 0.08$ & $9.53 \pm 0.21$ & $5.84 \pm 0.01$ & $6.70 \pm 0.03$ & $0.06 \pm 0.01$ \\
\hline $\begin{array}{l}\text { Refrigerator } \\
14 \text { Hari }\end{array}$ & $0.46 \pm 0.04$ & $4.40 \pm 0.03$ & $2.18 \pm 0.05$ & $7.70 \pm 0.25$ & $5.77 \pm 0.01$ & $6.80 \pm 0.02$ & $0.12 \pm 0.01$ \\
\hline $\begin{array}{l}\text { Ruang } 14 \\
\text { Hari }\end{array}$ & $1.35 \pm 0.04$ & $3.63 \pm 0.04$ & $1.60 \pm 0.11$ & $5.77 \pm 0.15$ & $5.73 \pm 0.01$ & $6.86 \pm 0.03$ & $0.25 \pm 0.01$ \\
\hline $\begin{array}{l}\text { Freezer } 21 \\
\text { hari }\end{array}$ & $0.37 \pm 0.04$ & $4.39 \pm 0.02$ & $2.36 \pm 0.13$ & $8.83 \pm 0.20$ & $5.77 \pm 0.01$ & $6.74 \pm 0.01$ & $0.31 \pm 0.01$ \\
\hline $\begin{array}{l}\text { Refrigerator } \\
21 \text { Hari }\end{array}$ & $0.60 \pm 0.02$ & $4.35 \pm 0.01$ & $1.90 \pm 0.13$ & $7.30 \pm 0.25$ & $5.67 \pm 0.01$ & $6.81 \pm 0.02$ & $0.41 \pm 0.01$ \\
\hline $\begin{array}{l}\text { Ruang } 21 \\
\text { Hari }\end{array}$ & $1.50 \pm 0.02$ & $3.55 \pm 0.01$ & $1.58 \pm 0.03$ & $4.73 \pm 0.21$ & $5.58 \pm 0.03$ & $6.95 \pm 0.03$ & $0.49 \pm 0.05$ \\
\hline
\end{tabular}

\section{SIMPULAN}

1. Terjadi interaksi antara lama penyimpanan dengan varian suhu penyimpanan kefir susu sapi ditunjukkan dengan perlakuan lama penyimpanan dan suhu penyimpanan yang memiliki nilai kurang dari $(\alpha=0.05)$ dapat dikatakan memiliki pengaruh nyata terhadap parameter total gula, total asam, $\mathrm{pH}$, total khamir, total bakteri asam laktat, kadar alkohol dan total padatan terlarut.

2. Perlakuan terbaik didapatkan pada suhu penyimpanan freezer dengan lama penyimpanan selama 7 hari (S1L1). Adapun karakteristik dari perlakuan terbaik yaitu $\mathrm{pH}$ sebesar 4.47 , total padatan terlarut sebesar $10.00 \%$ Brix, total gula

3. sebesar $3.07 \%$, total asam sebesar $0.26 \%$, kadar alkohol sebesar $0.04 \%$, total bakteri asam laktat sebesar 5.91 Log CFU/ml dan total khamir sebesar 6.56 Log CFU/ml.

\section{DAFTAR PUSTAKA}

Agustawa, R. 2012. Modifikasi Pati Ubi Jalar Putih (Ipomoea batatas L.) Varietas Sukuh dengan Proses Fermentasi dan Metode Heat Moisture Treatment (HMT) Terhadap Karakteristik Fisik dan Kimia Pati. Skripsi. Fakultas Teknologi Pertanian . Universitas Brawijaya Malang

AOAC. 1990. Official Methods of Analysis of The Association of Official Analytical Chemists. 
Kajian Analisis Suhu dan Lama Penyimpanan - Setiawati, dkk

Jurnal Pangan dan Agroindustri Vol.6 No.4: 77-86, Oktober 2018

AOAC Inc. Washington, DC

Apriyanto, A. Fardiaz, S. Puspitasari dan Budiyantono, S. 1989. Petunjuk Praktikum Analisis Pangan. Bogor. Institut Pertanian Bogor

Fardiaz, S. 1992. Mikrobiologi Pangan. Departemen Pendidikan dan Kebudayaan Direktorat Jenderal Perguruan Tinggi Pusat Antar Universitas Pangan dan Gizi. Bogor. Institut Pertanian Bogor

Fatwa Majelis Ulama Indonesia tentang Alkohol diakses (2009) di mui.or.id pada 20 Juni 2018 Pukul 22.00

Hidayat, N., Padaga, M.C., dan Suhartini S. 2006. Mikrobiologi Industri. Penerbit Andi. Yogyakarta

Hidayat, Ir., Kusrahayu. 2013. Total Bakteri Asam Laktat, Nilai Ph Dan Sifat Organoleptik Drink Yoghurt Dari Susu Sapi Yang Diperkaya Dengan Ekstrak Buah Mangga. Animal Agriculture Journal, Vol. 2. No. 1, 2013, p 160 - 167.

Hossain, T., Alam, M.K., dan Sikdar, D. (2012). Chemical And Microbiological Quality Assessment of Raw and Processed Liquid Market Milks of Bangladesh. Nigeria

Indah, A. 2017. Optimasi Suhu Dalam Pembuatan Kefir Susu Sapi dan Uji Aktivitas Antibakterinya Sebagai Minuman Probiotik. Skripsi. Universitas Islam Negeri Jakarta

Jeanette,L, Ketut, S., dan Luh P.T., 2015. Pengaruh Konsentrasi Sukrosa Terhadap Karakteristik Yoghurt Dari Susu Kulit Pisang Kepok (Musa Paradisiaca Formatypica) Dan Kacang Hijau (Phaseolus Radiatus L.). Jurnal Ilmu dan Teknologi Pangan. Denpasar. Universitas Udayana

Kinanti, L. 2014. Analisis Kadar Gula Reduksi, Kadar Gula Total Dan Kadar Pati. Bandung. Universitas Padjajaran

Mal, R., Radiati, L. E. dan Purwadi. 2015. Effect Of Storage Duration In Refrigerator Temperature On Ph Value, Viscosity, Total Lactic Acid And Profiles Protein Dissolved Of Goat Milk Kefir. Jurnal Teknologi Hasil Ternak. Malang . Universitas Brawijaya

Malaka, R. dan A. Laga. 2005. Isolasi dan identifikasi Lactobacillus bulgaricus strain ropy dari yoghurt komersial. J. Sains \& Teknol 5 (1): 50-58.

Mallesha., Shylaja, R., and Selvakumar, D.J.H., 2010. Isolation and Identification of Lactic Acid Bacteria from Raw and Fermented Products and Their Antibacterial Activity. Rec. Res. Sci. Technol. 2(6):42-46

Moore, E. 2009. Brix Refractometer to Monitor Total Solids in Milk

Sukandar, D. 2014. Aktivitas Antioksidan dan Mutu Sensori Formulasi Minuman Fungsional Sawo-Kayu Manis. Jurnal Kimia Valensi Vol. 4 No. 2, November 2014 (80-89). Jakarta. UIN Syarif Hidayatullah

Surono, I. S. 2004. Probiotik Susu Fermentasi dan Kesehatan. YAPMMI, Jakarta

Thai Agricultural Standard. 2010. Raw Goat Milk (TAS 6003 - 2010)

Usmiati, S. 2007. Pengaruh Suhu dan Lama Penyimpanan Terhadap Keasaman dan Kadar Alkohol Kefir. Teknologi Pengolahan Susu Balai Besar Penelitian dan Pengembangan Pascapanen Pertanian. Bogor

Wijaningsih, W .2008. Aktivitas Antibakteri In Vitro dan Sifat Kimia Kefir Susu Kacang Hijau oleh Pengaruh Jumlah starter dan Lama Fermentasi. Semarang. Universitas Diponegoro

Yulneriwarni, F., dan Noverita. 2008. FERMENTASI KEFIR DARI SUSU KACANG KACANGAN. VIS VITALIS, Vol. 01 No. 2, ISSN 1978-9513. Jakarta Universitas Nasional.

Yusriah, N., Hafidzoh dan Agustiana,R. 2014. Pengaruh Waktu Fermentasi Dan Konsentrasi Bibit Kefir Terhadap Mutu Kefir Susu Sapi . UNESA Journal of Chemistry 3:2, 53-57.

Zakaria, Y. 2013. Analisis Keasaman dan Total Bakteri Asam Laktat Yogurt Akibat Bahan Baku dan Persentase Lactobacillus casei yang Berbeda. Jurnal Agripet 13:2, 31-35.

Zeleny, M. 1992. Multiple Criteria Decision Making. Mc Graw Hill Book Company, New York 